Vol. $1-2019$

Engineering Research Journal

\title{
A new Solar Desalination System Design and Heat Recovery
}

\author{
S. A. El-Agouz ${ }^{1}$ M. Abdel Halim² $\quad$ A. M. Awad ${ }^{2}$ \\ ${ }^{1}$ Mech. Eng. Dept, Faculty of Eng, Tanta University, Egypt. \\ ${ }^{2}$ Mech. Dept, Faculty of Industrial Education, Suez University, Egypt.
}

\begin{abstract}
The work evaluates experimentally technique to improve fresh water production by careful energy recovery in the vapour condensation processes; the recovered heat in turn on drives additional evaporation and preheats the feedwater. A pilot plant is designed and constructed in an arid area with $\mathbf{2} \mathbf{m}^{2}$ solar evaporation collector area to evaluate the process. This unit is tested on cold and hot days. The effect of main parameters on fresh water production of the unit is studied. The experimental results show that, the production rate and efficiency of the system are strongly affected by solar radiation and level water in solar evaporation collector. Within the studied ranges, the maximum productivity reached to $16.1 \mathrm{~kg} / \mathrm{m}^{2}$ day at $T_{\text {vap,av }}=87.6^{\circ} \mathrm{C}$, solar radiation $842 \mathrm{~W} / \mathrm{m}^{2}$ and level water 1.912 kg. According to these results, fresher water production of the present system is higher than that solar still desalination system in the previous studies.
\end{abstract}

Keywords: Solar desalination system, evaporation, saline water, experimentally studied.

\section{Nomenclature}

$\mathrm{m}$

$\mathrm{T}$

I

$P_{d}$

$\mathrm{P}_{\mathrm{m}}$

$\mathrm{W}_{\text {speed }}$

Mass, $\mathrm{kg}$.

Temperature, ${ }^{\circ} \mathrm{C}$.

Solar Radiation, $\mathrm{W} / \mathrm{m}^{2}$.

Accumulated Productivity, kg/day.

Productivity Rate, g/min.

Wind Speed, $\mathrm{m} / \mathrm{s}$.

$\begin{array}{ll}\begin{array}{ll}\text { Subscripts } \\ \text { vap }\end{array} & \text { Vapour } \\ \text { av } & \text { Average } \\ \text { in } & \text { Inlet. } \\ \text { f } & \text { Fresh. } \\ \text { s } & \text { Supply } \\ \text { w } & \text { Water. } \\ \text { abs } & \text { Absorber. } \\ \text { amb } & \text { Ambient. } \\ \text { g } & \text { Glass }\end{array}$

Abbreviations

FWR Fresh water reservoir

TES Thermal Energy Storage.

MED Multiple-Effect Diffusion.

$\begin{array}{ll}\text { SVC } & \text { Solar Evaporation collector. } \\ \text { CV } & \text { Control Level Valve. } \\ \text { HD } & \text { Header. } \\ \text { HX } & \text { Heat Exchanger. }\end{array}$

\section{INTRODUCTION}

Solar water desalination is the future of the world due to the scarcity of freshwater sources and the energy of fossil fuels. Solar energy is the ideal renewable energy alternative because it is clean and durable. Solar desalination is a prerequisite in places where there is no fresh water and energy sources. Desalination of seawater and brackish water has been implemented on a large scale throughout the world.

The availability of fresh water is diminishing continuously day by day because of global warming and climate change. Same time, its requirement is increased rapidly all over the world due to rapid growth of population. Therefore, the availability of good quality of drinking water is the major challenge in front of developing as well as developed countries. About $97.5 \%$ of the total water available on the earth having salt and harmful bacteria, nearly $2 \%$ is frozen in glaciers and polar ice caps, Kumar et al. [1].

El-agouz et al. [2] the designed the low temperature desalination system using solar collectors within the studied ranges, the maximum daily productivity reached to $9 \mathrm{~L} / \mathrm{m}^{2}$ day. George et al. [3] presents an experimental demonstration of a salt-rejecting evaporation structure that can operate continuously under sunlight to generate clean vapor while floating in a saline body of water such as an ocean. The evaporation structure is coupled with a low-cost polymer film condensation cover to produce freshwater at a rate of 2.5 $\mathrm{L} / \mathrm{m}^{2}$.day, material cost is $3 \$ / \mathrm{m}^{2}$, does not require energy infrastructure, and can provide cheap drinking water.

The experiments composed of two flat plate solar collectors connected in series, and a solar still equipped with a heat exchanger. After heated in the collectors, the nanofluid enters the heat exchanger installed in the solar still basin to exchange heat with brackish water. The experiments are conducted two sizes of nanoparticles (7 and $40 \mathrm{~nm}$ ), two 
Vol. $1-2019$

depths of water in the solar still basin (4 and $8 \mathrm{~cm}$ ), and three mass flow rates of nanofluids during various weather conditions. The results reveal that using nanofluids is enhancing the performance indices about $10 \%$. At higher temperatures (e.g. $70{ }^{\circ} \mathrm{C}$ ), Omid Mahiana et al [4]. Performance evaluation of double slope single basin solar still with circular and square cross-sectional hollow fins. Mild steel circular hollow fins and mild steel square hollow fins were welded upon two different mild steel absorber plates. The maximum distilled water output of $1.4917 \mathrm{~kg} / \mathrm{m}^{2}$.day was obtained from the circular finned solar still for the $10 \mathrm{~mm}$ basin water depth, whereas the square finned solar still was achieved the maximum distilled water output of 0.9672 $\mathrm{kg} / \mathrm{m}^{2}$.day, by Hardik and Kalpeshkumar [5].

Arjunan et al. [6] conducted experiments in a single slope solar still with sponge cubes of various thickness inside the basin to improve the heat utilization during nocturnal hours. It results from the study that the productivity of the solar still increases with decrease in sponge thickness. Ayoub et al. [7] used a rotating drum inside the basin to improve heat transfer rate. The drum inside the solar still increases the evaporative surface area of the water and this improves the freshwater yield as compared to systems without rotating drum. Gude et al. [8] designed the low temperature desalination system using solar collectors augmented by thermal energy storage. A solar collector area was $15 \mathrm{~m}^{2}$ with $1 \mathrm{~m}^{3}$ of Thermal Energy Storage (TES) volume or $18 \mathrm{~m}^{2}$ with $3 \mathrm{~m}^{3}$ of TES volume. The results show that the fresh water production can reach $6.67 \mathrm{~L} / \mathrm{m}^{2}$ day. solar collector. Mohamed et al. [9] studied the performance of single slope solar still coupled with phase change materials as a thermal storage unit and its effect on the still productivity. The results revealed that the presence of phase change material negatively affects the daytime freshwater productivity with a significant increment in the overall freshwater yield of the still. Additionally, placing steel wool fibers in the basin accompanied with phase change material significantly enhances the daytime freshwater productivity with a considerable reduction in overnight productivity and an increase of the overall day productivity. Among all tested configurations, with steel wool fibers achieves the highest accumulated daily freshwater productivity and thermal efficiency with minimum cost. Manokar et al. [10] have experimentally studied the single slope solar still with PV panel, the maximum productivity of $7.3 \mathrm{~kg} / \mathrm{m}^{2}$ day. Joy et al. [11] experimentally studied the single slope solar still with hot air blower to enhance the system productivity. The solar still yielded $5 \mathrm{~L} / \mathrm{m}^{2}$ day. Hiroshi Tanaka et al. [12] studied A single-effect diffusion still, instead of a multiple-effect diffusion (MED) still, combined with a tilted wick still was investigated
Engineering Research Journal

experimentally under actual weather conditions. From the experiments in summer and autumn, it was found that an MED still can be heated in both seasons whether the MED still absorbs solar radiation directly or not. The maximum of experiments was about $4.88 \mathrm{~kg} / \mathrm{m}^{2}$.day when total solar radiation $18.4 \mathrm{MJ} / \mathrm{m}^{2}$.day. Gnanaraj et al. [13] experimentally investigated the conventional solar still and modified double basin solar still for productivity enhancement. The double basin solar still with reflector coupled FPC and mini solar pond gave a productivity of $6.25 \mathrm{l} / \mathrm{m}^{2}$.day.

The main objectives of the present work are to describe the new design for solar still distillation system coupled with saving energy to enhance productivity and efficiency. The paper presents the results of a new solar distillation system, with the water working in an open loop. The evaporation takes place in solar heater. The new system is designed to improve the evaporation rate and save energy by spraying water at inlet water system on hot rod made of copper. The energy required for thermal distillation is the same evaporation energy of water saline.

\section{PROCESS DESCRIPTION}

Figs. 1 and 2 show, respectively, a schematic diagram and a photo of the experimental setup of the new solar water desalination unit. The developed unit operates at atmospheric pressure using solar evaporation collector to produce vapor. Three parts constitute the installation: solar vapour collector, latent heat recovery, and heat exchanger.

The principle of the process of desalination is as follows. The saline water is filled up to a specified level into the solar evaporation collector (SVC) by the control level valve (CV) .The saline water heated and evaporation by solar absorber. The vapour leaves into header (HD) where the copper rod is heated. Entrance of saline water to the system leads to its heating by condensation the steam in heat exchanger (HX). Hot water enters the sprinklers which water spray the amount of saline evaporate by heat absorption from saline and the other amount evaporate by spray onto the hot copper rod by absorption heat and produce a steam then leaves in to heat exchanger (HX). Saline water that is not evaporated in the bottom leave into the solar evaporation collector. The heat exchanger (HX) condenses vapour water by heat exchange with saline water make up then exit in to sprinklers. Distilled water is collected leave into a fresh water tank (FWR). The $2.0 \mathrm{~m}^{2}$ solar collector as shown in Figure 2 is the main component of the unit. In fact, their properties have an important effect on the operation and effectiveness of the unit. Contains an absorption plate containing parallel copper pipes spaced uniformly each pipe consists of bottom a small 
Vol. $1-2019$

diameter and high a larger diameter to facilitate evaporation due to the varying density of the steam. It is a coated black surface to increase system uptake. It is insulated with 50.0 $\mathrm{mm}$ thickness of insulating glass wool and aluminum layer, thermal conductivity is $0.036 \mathrm{~W} / \mathrm{m}^{2} \mathrm{k}$. The Heat Exchanger
Engineering Research Journal

(HX) is constructed from a cylindrical casing of $1.0 \mathrm{~mm}$ copper sheets with dimensions of $\phi 100.0 \times 310.0 \mathrm{~mm}$ and vertical parallel tubes with dimensions of $\phi 10.0 \times 280.0 \mathrm{~mm}$. Heat exchanger with entrances the enter and exit of cooling water and enter the steam and exit condensate fresh water.
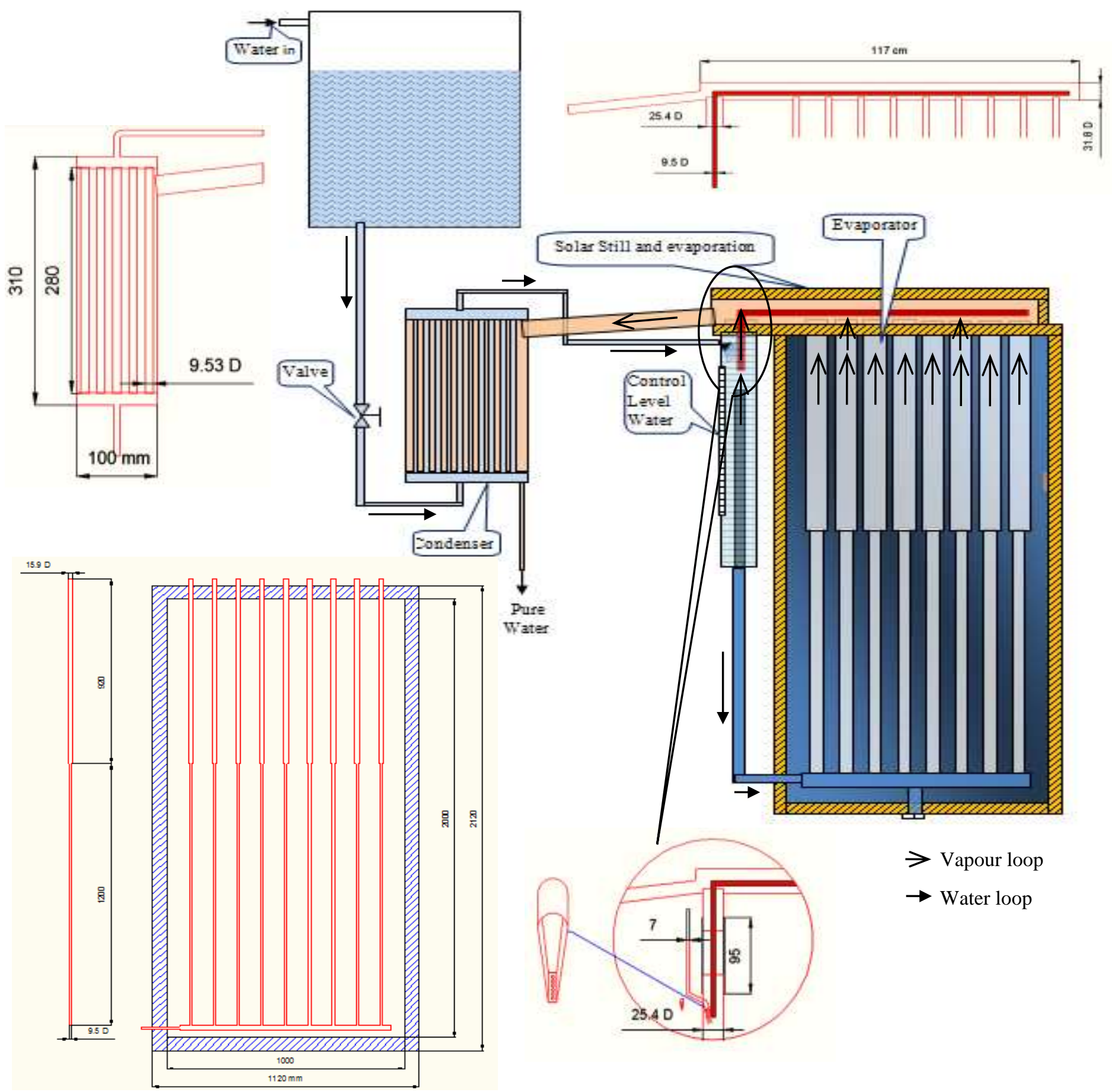

Fig. 1. Schematic diagram of solar water desalination unit. 


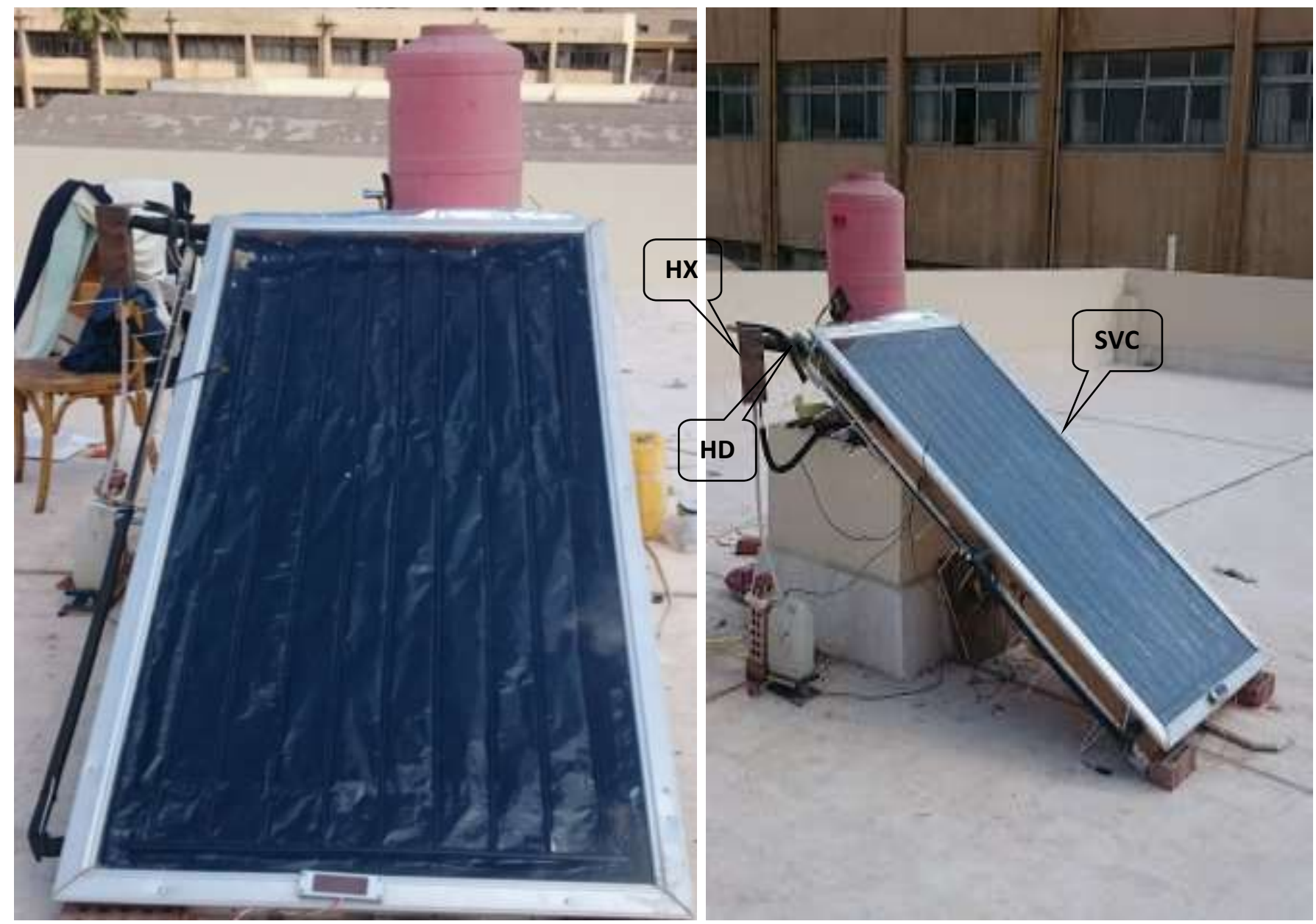

Fig. 2. Photo of the experimental setup of solar water desalination unit.

\section{INSTRUMENTATION}

As shown in Fig. 1, waterproofed sensors model DS18B20 with a measure range of -55 to $125{ }^{\circ} \mathrm{C}$ is used to measure the temperature of the water of the inlet and outlet of the solar water collector (SVC), inlet and outlet of heat exchanger (HX), glass temperature, solar absorber surface temperature and ambient temperature. The sensors are attached to an arduino board (reading and data logger) with an accuracy $\pm 0.1{ }^{\circ} \mathrm{C}$ that is connected to a computer. Level water in solar evaporation collector is regulated automatic by means of a solinde valve in the entering line of the solar evaporation collector by arduino board. The fresh water weight is measured by using a weight sensor with a range of 0 to $50 \mathrm{~kg}$ and an accuracy of $\pm 5 \mathrm{~g}$ are attached data to the arduino board (reading and data logger). The solar radiation is measured by using both TD 208 b-solar meter and a silicon cell pyranometer model 3120 of an accuracy of $\pm 1 \mathrm{~W} / \mathrm{m}^{2}$ and logger data in arduino board. Moreover, an anemometer (digital turbofan) of an accuracy $\pm 0.1 \mathrm{~m} / \mathrm{s}$ measures the wind speed recorded every one hour. The temperature, solar radiation and weight of fresh water is recorded every $30 \mathrm{~S}$ by arduino board. To estimate the uncertainties in the results presented in this work, the approach described by Barford [14] is applied. The uncertainty in the measurements is defined as the root sum square of the fixed error of the instrumentation and the random error observed during different measurements are showing in table 1.

TABLE 1. Error Measurement.

\begin{tabular}{|c|c|c|c|}
\hline Instruments & Accuracy & Range & \% error \\
\hline Thermocouple & $\pm 0.4^{\circ} \mathrm{C}$ & $0-125^{\circ} \mathrm{C}$ & $0.32 \%$ \\
\hline $\begin{array}{c}\text { Solar power } \\
\text { meter }\end{array}$ & $\pm 1 \mathrm{~W} / \mathrm{m}^{2}$ & $\begin{array}{c}0- \\
2500 \mathrm{~W} / \mathrm{m}^{2}\end{array}$ & $2.5 \%$ \\
\hline Anemometer & $\pm 0.1 \mathrm{~m} / \mathrm{s}$ & $0-15 \mathrm{~m} / \mathrm{s}$ & $1.1 \%$ \\
\hline $\begin{array}{c}\text { Measuring } \\
\text { weight }\end{array}$ & $\pm 5 \mathrm{~g}$ & $0-50 \mathrm{~kg}$ & $0.01 \%$ \\
\hline $\begin{array}{c}\text { Total } \\
\text { productivity }\end{array}$ & $\pm 5 \mathrm{~g}$ & $32.2 \mathrm{~kg}$ & $0.016 \%$ \\
\hline
\end{tabular}

\section{EXPERIMENTAL RESULTS}

The amount of distillate water produced by the units depends on the solar collector size. The performance of the collector depends mainly on the weather conditions, design and operating parameters. However, to estimate the optimum values of these parameters in different weather conditions using full experiment. The desalination unit is tested in a certain period of time, including hot and cold days. Examining the performance of setup for each test takes one day in real conditions of various days and in each test in the early hours of the day. Desalination unit starts when water in the solar collector reaches an 
Vol. $1-2019$

appropriate evaporation temperature and fresh water production begins. The productivity can start early in the morning at 9 O'clock when the absorber surface temperature of the solar collector $90^{\circ} \mathrm{C}$. The solar radiation, wind speed and ambient temperature variation with time at different level filled water on the solar evaporation collector are shown in Fig. 3.

\section{Temperatures versus Time for Different Operating \\ Parameters}

The temperature variation of the inlet and outlet of solar evaporation collector, evaporation tube, and the heat exchanger, surface temperature and glass temperature with time at different level fill water are shown in Fig. 4 the fresh water temperature increase with increasing ambient temperature. The maximum fresh water temperature at time $1.0 \mathrm{pm}$.

\section{The Productivity Rate of the Desalination Unit}

The productivity rate of the unit and solar intensity with time is shown in Fig. 5. The maximum productivity rate at afternoon (12 clock) higher than any hours, because high solar intensity in this time. The system produce water at solar intensity above 790 and $780 \mathrm{~W} / \mathrm{m}^{2}$ at 1.77 and $1.912 \mathrm{~kg}$ for mass water filled of respectively and less than that does not produce.

\section{Accumulated Productivity of the Desalination Unit}

Fig. 6 shows accumulated productivity at different level water on solar evaporation collector. The productivity of the unit on hot and cold days. On both of these days, the unit starts at 9.5 o'clock. Because of higher solar intensity of hot days, the productivity on these days is higher than that on cold days. On cold days, because of lower solar intensity and thus, reduction of the temperature of the absorber, productivity sharply productivity reduces after about $5.5 \mathrm{~h}$ from the start time on a hot day. The maximum productivity at maximum solar intensity. The maximum accumulated productivity is about 16.09 and $15.06 \mathrm{~kg} / \mathrm{m}^{2}$ at 1.912 and 1.77 $\mathrm{kg}$ for mass filled of water (level water) respectively.

\section{Engineering Research Journal}

Accumulated Productivity and Vapour Temperature versus Time:

The variation of accumulated productivity with vapour temperature is presented in Fig. (7). the experimental data are performed level water in solar evaporation collector of 1.77 and $1.912 \mathrm{Kg}$. As shown the fresh water productivity produce at vapour temperature above $70^{\circ} \mathrm{C}$ and less than that does not produce. That is because of low solar intensity can't add latent heat for evaporative.

\section{Effect Solar Radiation and Average Vapour Temperature on Accumulated Productivity:}

As shown Fig. 8 and Fig. 9 the accumulated productivity increase with increasing average vapour temperature and average solar radiation. As shown the fresh water productivity increases with increase level water in solar evaporation collector at same the solar radiation. Whenever the solar radiation increase the vapour temperature increased.

\section{CONCLUSIONS}

Significant effects of the vapour temperature and solar radiation of productivity and efficiency of solar desalination system are observed during the present experiments and the following points are concluded:

- The level water for solar evaporation collector and solar radiation has an important effect on productivity.

- The increase in level water increases productivity at the same average vapour temperature.

- Within the studied ranges, the maximum productivity of the system reached to $16.1 \mathrm{~kg} / \mathrm{m}^{2}$ day at $\mathrm{T}_{\text {vap,av }}=87.6^{\circ} \mathrm{C}$, solar radiation $842 \mathrm{~W} / \mathrm{m}^{2}$ and level water $1.912 \mathrm{~kg}$. For saline water.

- The maximum productivity of $16.1 \mathrm{~kg} / \mathrm{m}^{2}$ day of solar evaporation collector which is relatively higher than previously published $[2,8,11,12$, and 13$]$.

- The maximum productivity in the new desalination system is higher than solar still desalination system. 
Vol. $1-2019$
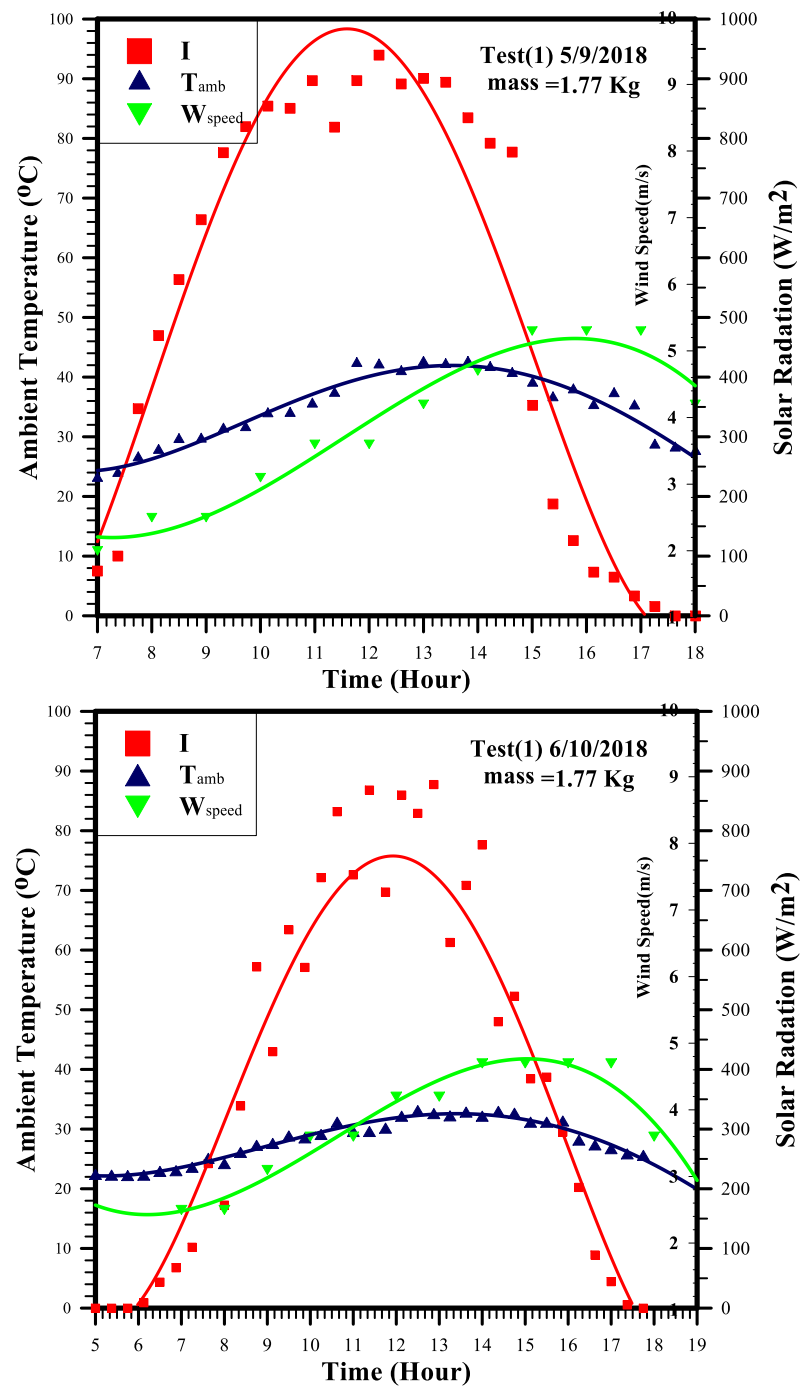

Engineering Research Journal
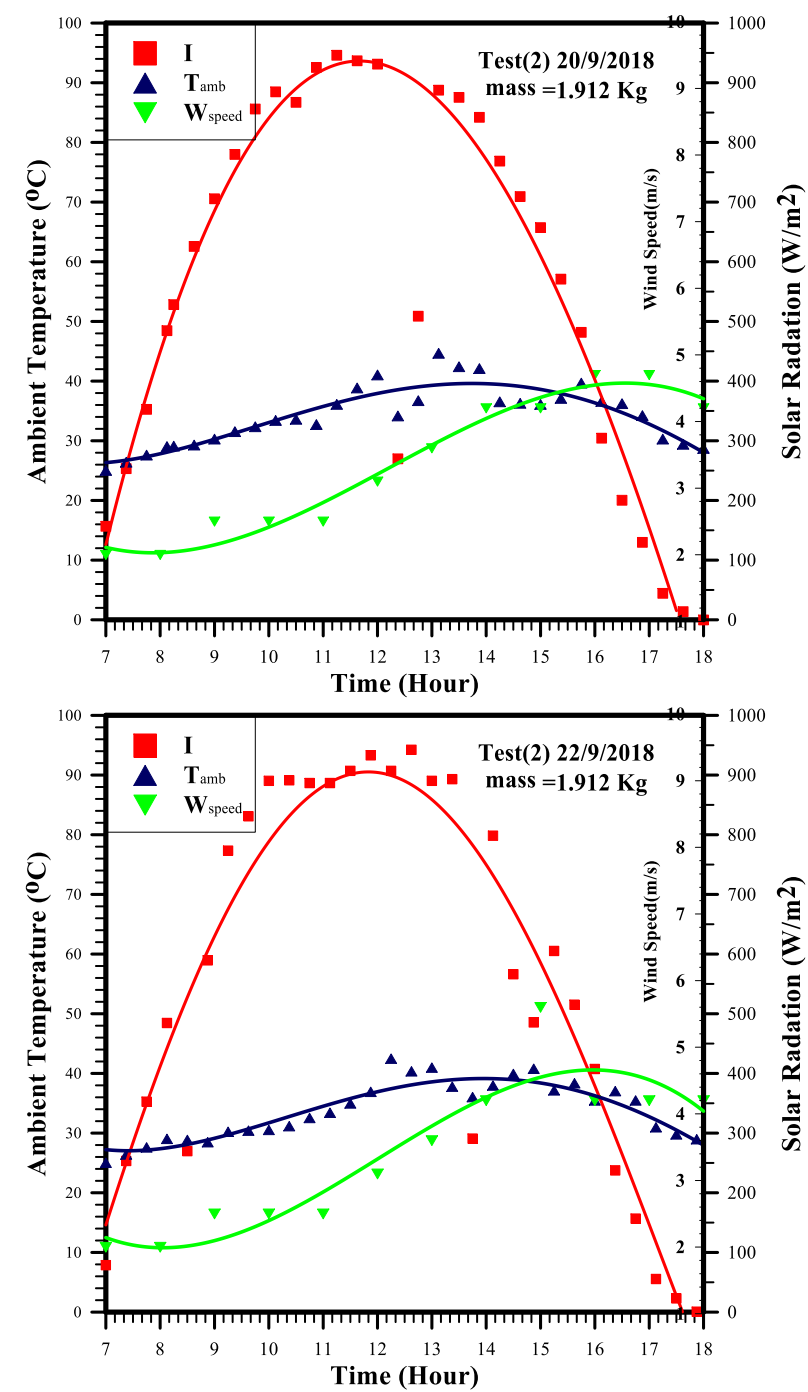

Time (Hour)

Fig. 3. Solar radiation, wind speed and ambient temperature variation in different level fill water.
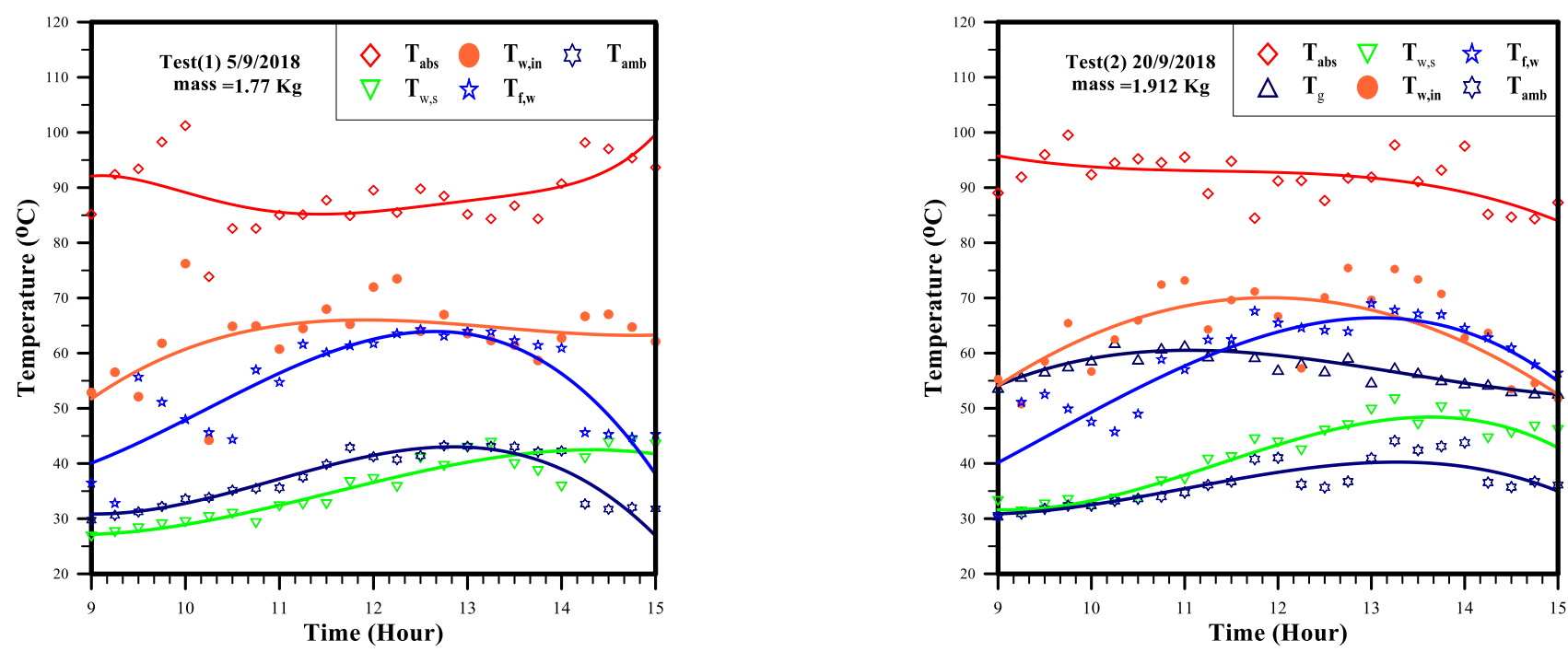

Fig. 4. Temperatures versus Time for Different Operating Parameters. 
Vol. 1 - 2019

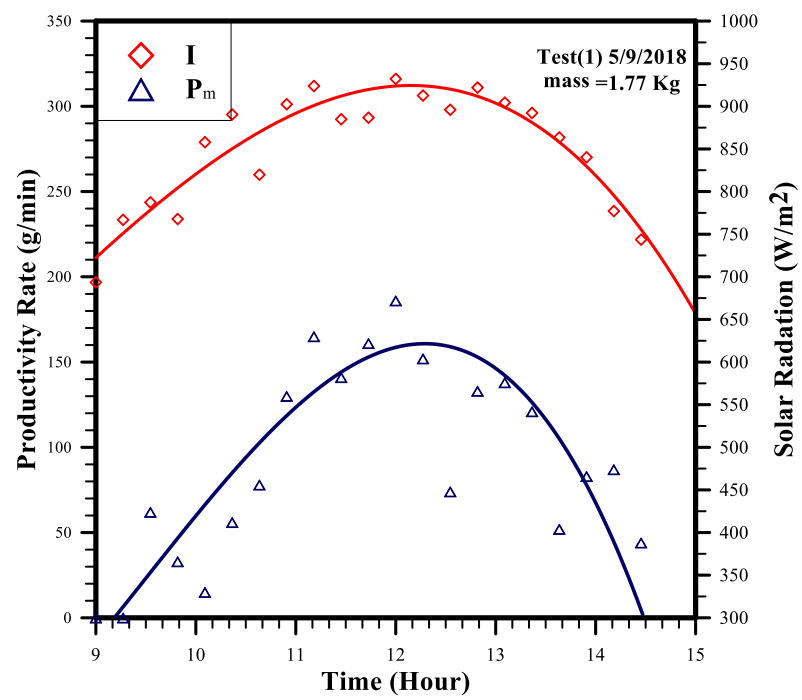

Engineering Research Journal

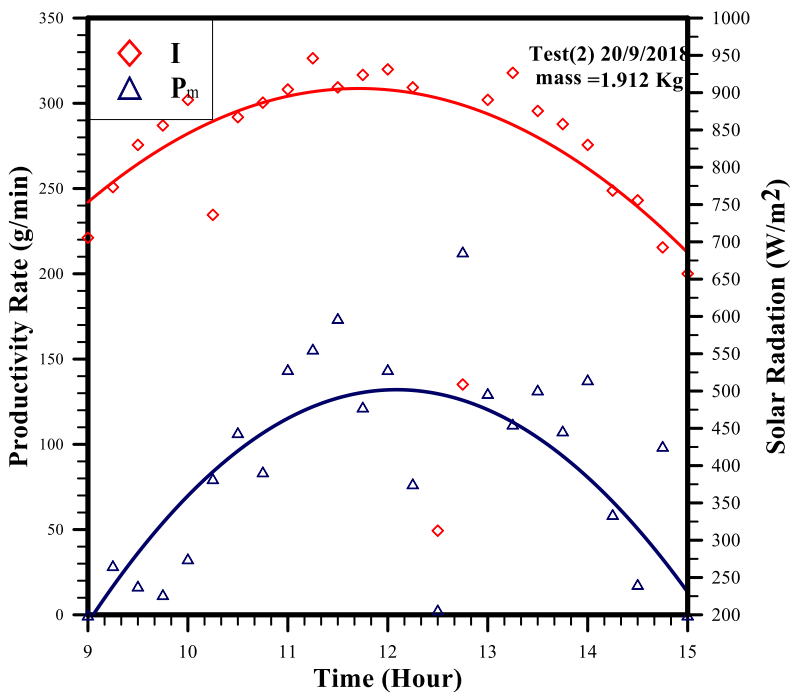

Fig. 5. Productivity rate at different day and level water.
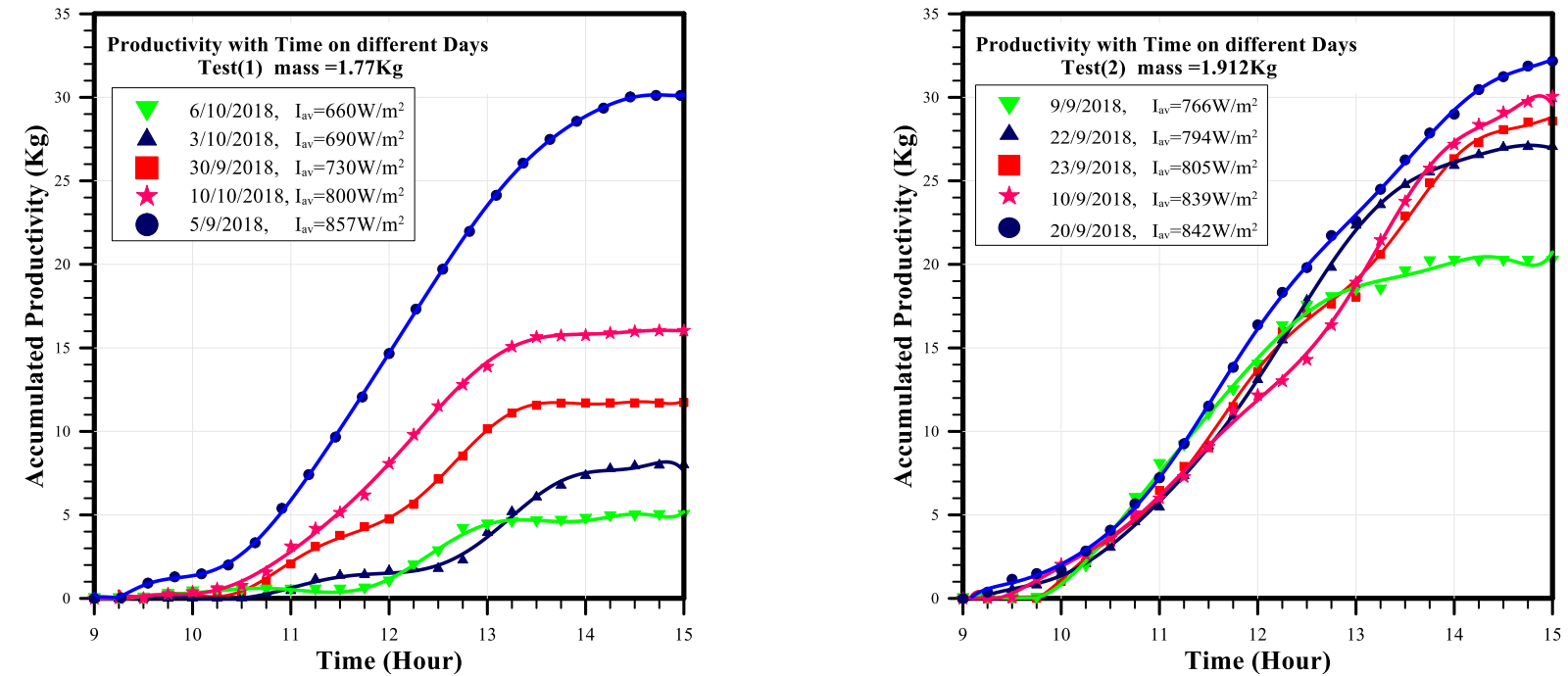

Fig. 6. Accumulated productivity at different day and average solar radiation.
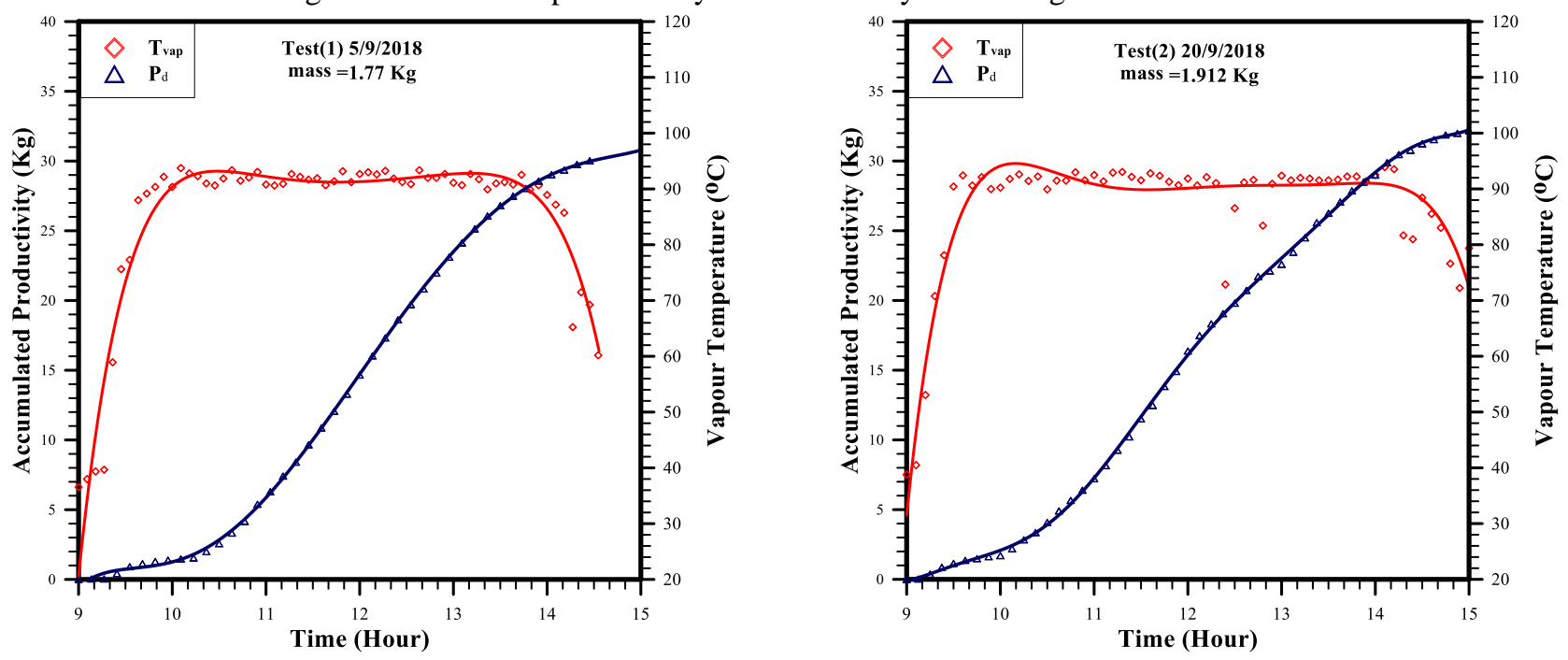

Fig. 7. Accumulated productivity and vapour temperature with time at different days. 
Vol. 1 - 2019

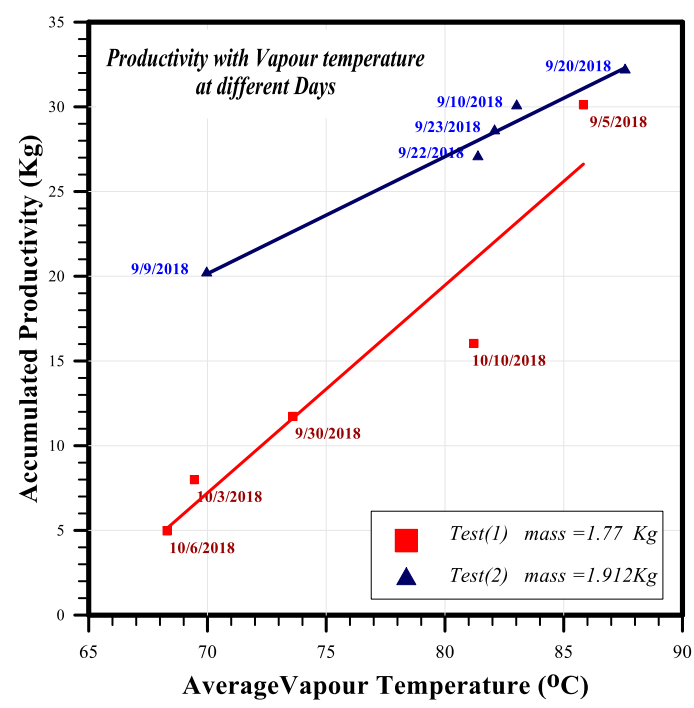

Fig. 8. Accumulated productivity with average vapour temperature at different days and level fill water.

\section{REFERENCES}

[1] P.V. Kumar, A. Kumar, O. Prakash and A.K. Kaviti. Solar stills system design: a review. Renew. Sustain. Energy Rev. 2015; 51: pp. 153-181

[2] S.A. El-Agouz a, G.B. Abd El-Aziz b and A.M. Awad. Solar desalination system using spray evaporation. Energy 2014; 76: 276-283

[3] Ni. George, Seyed Hadi Zandavi, Seyyed Morteza Javid, Svetlana V. Boriskina, Thomas A. Cooper and Gang Chen. A salt-rejecting floating solar still for low-cost desalination. Energy \& Environmental Science;2018 11: 1510-1519.

[4] OmidMahian, AliKianifar, Saeed ZeinaliHeris, DongshengWen, Ahmet Z.Sahin and Somchai Wongwises. Nanofluids effects on the evaporation rate in a solar still equipped with a heat exchanger. Nano Energy, 2017; 36: 134-155.

[5] K. Hardik Jani and Kalpeshkumar Vasantbhai Modi. Experimental performance evaluation of single basin dual slope solar still with circular and square cross-sectional hollow fins. Solar Energy, 2018; 179-186.

[6] T.V. Arjunan, N.Nedunchezhian and. HS Aybar. Effect of sponge liner on the internal heat transfer coefficients in a simple solar still. Desalination and Water Treatment; 2011: 29. 271-284.

[7] G.M. Ayoub, M. Al-Hindi and L. Malaeb. A solar still desalination system with enhanced productivity. Desalination and Water Treatment; 2015: 53. 3179-3186.

[8] V.G. Gude, N. Nirmalakhandan, S. Deng and A. Maganti . Low temperature desalination using solar collectors
Engineering Research Journal

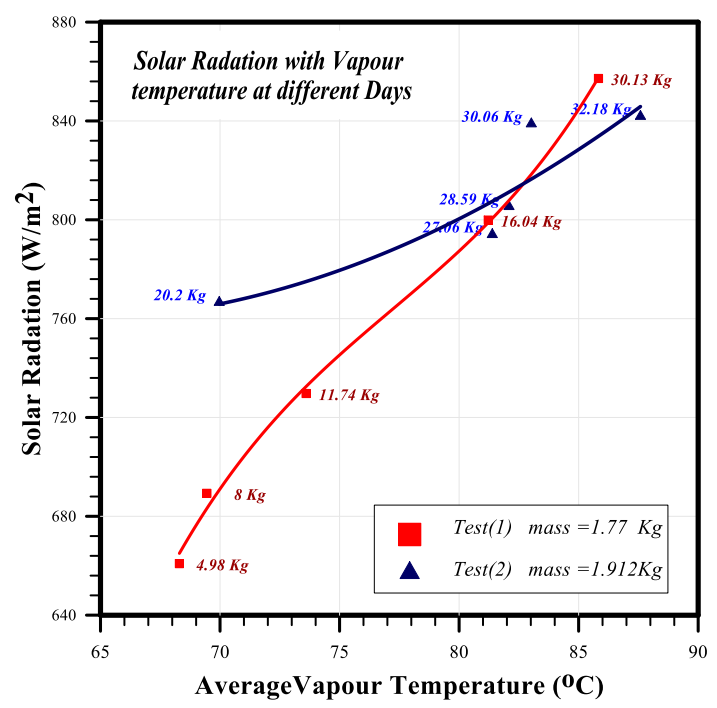

Fig. 9. Solar radiation with average vapour temperature at different day and level fill water.

augmented by thermal energy storage. Applied Energy 2012; 91: 466-74.

[9] S. Mohamed Yousef and Hamdy Hassan. An experimental work on the performance of single slope solar still incorporated with latent heat storage system in hot climate conditions. Journal of Cleaner Production 2019; 209: 1396-1410.

[10] A.M. Manokar, D.P. Winston, A.E. Kabeel and R. Sathyamurthy. Sustainable fresh water and power production by integrating $P V$ panel in inclined solar still. Journal of Cleaner Production 2018; 172 : 2711-2719.

[11] Nivin Joy, Alphonsa Antony and A. Anderson. Experimental study on improving the performance of solar still using air blower. International Journal of Ambient Energy 2017;39: 1-4.

[12] Hiroshi Tanaka, Koji Iishi. Experimental study of a vertical single-effect diffusion solar still coupled with a tilted wick still. Desalination 2017; 402: 19-24.

[13] S. Joe Patrick Gnanaraj, S. Ramachandran and David Santosh Christopher. Enhancing the design to optimize the performance of double basin solar still. Desalination, 411 (2017), pp. 112-123.

[14] N. C. Barford Experimental measurements: precision., error and truth. 2nd ed. New York: John Wiley \& Sons; 1990. 